\title{
Impact of Local Economic Activity Zones on Socio-Economic Development of Rural Areas
}

\begin{abstract}
One of the most important concepts in rural geography is the multifunctional development. In this concept, the postulated increase in the number of business entities is to lead to an improvement in the socio-economic situation. One of the ways to achieve multifunctionality may be creating local economic activity zones (LEAZ). They are created to stimulate entrepreneurship in local scale. The main purpose of the work is to determine the impact of local economic activity zones on selected factors describing socio-economic development of rural areas. The following research questions were posed: (1) In the communes after creating LEAZs, were the indicators of socio-economic development higher than the average in rural areas of voivodeship? (2) In the communes where LEAZs exist, were the indicators of socio-economic development higher within five years after the creation of LEAZs than before? (3) In the urban-rural communes where LEAZs work, were the effects more significant in the rural areas or in the city? In the research procedure, the index of average annual dynamics (the rate of change) and the Mann Whitney $U$ test test were used primarily. The analysis shows that the average values of the dynamics in change indicators in the areas where LEAZ operates are higher or comparable with the average value for the rural areas. The study diagnosed the beneficial effect of the presence of large business entities in the LEAZ on employment growth in rural areas.
\end{abstract}

Keywords: local economic activity zone; multifunctional development; Poland; rural areas; socio-economic development

Received: 11 December 2019

Accepted: 14 February 2020

Suggested citation:

Wojtyra, B. (2020). Impact of Local Economic Activity Zones on Socio-Economic Development of Rural Areas. Studies of the Industrial Geography Commission of the Polish Geographical Society, 34(1), 62-79. doi: $10.24917 / 20801653.341 .5$

\section{INTRODUCTION}

As a result of the political and economic transformation initiated in Poland at the end of the 1980s, commune self-governments were created. The communes received a real influence on the process of the socio-economic development (Jarczewski, 2007). In the meantime, as a consequence of the change a centrally planned economy to a free 
market centrally planned economy to a free market economy, the conditions of the enterprises operating have changed. What is more, the inflow of the foreign capital to Poland increased gradually and the investment attractiveness improved significantly, especially after the country's accession to the structures of the European Union in 2004.

From the beginning of the 1990s, the Polish countryside has undergone changes as well. Currently, the dominant paradigm in its development is multifunctionality, which is a response to the decline in the importance of agriculture in the economy. Usually, it is identified with the introduction of the new non-agricultural functions into the economic space of rural areas. In this concept, the postulated increase in the number of business entities is to lead to an improvement in the socio-economic situation, including the quality of life of the rural areas inhabitants (e.g. Kłodziński, 1996; Knickel and Renting, 2000; van Huylenbroeck and Durand, 2003; van der Ploeg and Roep, 2003; Woods, 2005).

Local economic activity zones have become one of the many forms of increasing the investment attractiveness of rural areas and, at the same time, creating non-agricultural jobs (Wojtyra, 2014, 2017). As a result of legal regulations, including primarily the Act of 20 October 1994 on special economic zones, they have been a common instrument of pro-investment policy. Incentives targeted at entrepreneurs usually as tax breaks and areas prepared for investment took the form of an institutional factor for the location of economic activity (Stryjakiewicz, 1999). The development of entrepreneurship is one of the most important foundations of local socio-economic development (e.g. Blakely, Bradshaw, 2002). It is confirmed that also in rural areas where it is an opportunity to overcome the problems described in the circle of declining rural regions (The New Rural Paradigm..., 2006: 32). Thus, the local authorities undertake pro-investment activities through the use of local interventionism, e.g. in the form of the LEAZs, to improve the conditions for locating economic activity.

\section{PURPOSE, SCOPE, AND SOURCES}

The main purpose of the work is to determine the impact of selected local economic activity zones operating in the Wielkopolskie voivodeship on the development of rural areas, in particular through indicating the impact on selected factors, such as the number of enterprises, population, employed persons, dwelling stock, or the revenue of the commune per capita.

The following research questions were posed:

1. In the communes after creating LEAZs, were the indicators of socio-economic development higher than the average in rural areas of voivodeship?

2. In the communes where LEAZs exist, were the indicators of socio-economic development higher within five years after the creation of LEAZs than before?

3. In the urban-rural communes where LEAZs work, were the effects more significant in the rural areas or in the city?

The territorial scope includes rural areas of the Wielkopolskie voivodeship, delimited according to the administrative criteria based on the National Official Register of the Territorial Division of the Country (TERYT). According to this delimitation, rural communes and the rural part of urban-rural communes are assumed: 93 urban-rural (city and countryside belong to one commune) and 114 rural. On the one hand, the paper does not include local economic activity zones located in cities with poviat status 
and urban communes. On the other hand, economic activity zones located in citie s in urban-rural communes were taken into account, due to their often peripheral location of the commune (in the so-called urban-rural continuum), effects of actions serving the development of the entire local government, including rural areas, and the importance of smaller, local urban centres in the development of rural areas (e.g. Heffner, 2002, 2003, 2005; Heffner, Marszał, 2005). In addition, in the case of budget revenues of communes, due to aggregated available data, the urban and rural parts of communes were not distinguished.

The Wielkopolskie voivodeship was selected for the study, because it is characterised by a low level of remoteness and a relatively high socio-economic development of rural areas (Stanny, 2011). The subzones of five Polish special economic zones were located in this region, despite none of them has its headquarters there. Therefore, the Wielkopolskie voivodeship is a good example of the SEZ 'budding' process (Matykowski and Siwek, 2008). In addition, the region is historically linked with traditions of entrepreneurship and economy.

The time range of the research is 1995-2018. This period includes five years before the creation of the oldest LEAZ and five years of operation of the youngest LEAZ from the study group.

The Local Data Bank of the Statistics Poland was the main source of statistical data. Besides, information presented on official portals of commune offices, special economic zones, and The Investors and Exporters' Service Centre of the Wielkopolska Region were used.

The remainder of this paper is divided into five sections. In the next section, terminology used and theoretical background are discussed. In the second part, the attention is paid to the characteristic of the local economic activity zones in rural areas of the Wielkopolskie voivodeship. The third section explains methods. In the fourth part the results and limitations are discussed. Finally, the relevant conclusions are drawn.

\section{TERMINOLOGY AND THEORETICAL BACKGROUND}

The concept of the local economic activity zones (functioning in fact under various terms) in scientific literature and in the environment of local governments has not been clearly defined so far (Wojtyra, 2014). It is in contrast to special economic zones which are defined in Polish law. According to the legal definition, SEZ are separate, uninhabited parts of the territory of Poland, in which business activity may be conducted on the terms obtained in the Act of 20th October 1994 on Special Economic Zones (consolidated text: Journal of Laws of 2019, item 482). In fact, the SEZs consists of preferential conditions for investing, e.g. tax benefits for investors in the zone, but also numerous obligations (e.g. the need to maintain a business for a certain period of time). There are 14 special economic zones (SEZs) in Poland, mainly in the form of subzones scattered throughout the country. On 31th December 2016, they covered areas located in 179 cities and 287 communes, with a total area of $21,462.6$ ha (Information on implementation..., 2017).

An alternative solution for creating a subzone of a special economic zone may be the creation of local economic activity zones which are managed and created by the local government as "separated and prepared for investment areas corresponding to the needs of potential investors" (Stanienda 2011: 257). According to The Investors and Exporters' Service Centre, the economic activity zones "have a key importance for the 
spread of commercial investments, significantly increase the region's investment attractiveness, develop entrepreneurship, and create new jobs. Noticing the positive effects of such zones, communes consolidate new areas, build technical infrastructure, and change the purpose of the area in the local land use plans. As a result, the number of economic activity zones is steadily increasing". In practice, investors establishment of the business in the local activity zone may also count on positive fiscal conditions and exemptions from e.g. property tax.

Therefore, the Local Economic Activity Zone (LEAZ) is an investment area:

- privileged, through preferential fiscal conditions (e.g. tax breaks) available to entrepreneurs who want to start business activity in its area,

- partly formalised (e.g. through the Local Plan or resolution/agreement; Wojtyra, 2019).

In many cases, the LEAZ area is infrastructurally prepared, its implementation results from the strategic development policy of the commune, and its main goal is to increase entrepreneurship (Wojtyra, 2016). The zones identified for this study are active. It means that economic entities operate in their area. In other words, the activation process has been completed or is in progress.

Local economic activity zones are usually based on the model of special economic zones' functioning. Often these two form of zones are adjacent. What is more, after 2026, the existing special economic zones are going to be transformed into local economic activity zones. Thus, the responsibility for the creation and functioning of these areas will be in the future transferred to local self-governments (Allen, Tynel, 2011). In conclusion, the subzone of the special economic zone located can be practically treated as LEAZ; because, their effects will be measurable in commune from the local government point of view.

The operation of local economic activity zones should bring specific development effects in rural areas. The main expected, positive economic effects include:

- increase in the commune's revenue from property taxes and others in connection with the development of entrepreneurship;

- increase in residents' income and the diversification of the local labour market and the emergence of non-agricultural sources of income, in connection with the increase in employment in new enterprises;

- multiplier effects, such as stimulation of entrepreneurship as a result of creating local demand related to the activities of suppliers, customers, subcontractors, etc. under the influence of launching the local economic activity zone (Domański et al., 2001; Rachwał, Wiedermann, 2008; Tobolska 2010; Domański, Gwosdz, 2010). The second group - social effects, especially in the case of large enterprise emergence in the zone, include the improvement of the situation on the labour market (more jobs), opportunities for retraining and professional development for people worked in agriculture or unemployed before, development of housing construction and social infrastructure.

The third group includes spatial effects, such as the development of technical infrastructure e.g. building and modernization of roads and sewage, water, and gas system, as well as creation of new spatial connections caused by commuting to work and taking over the area for new functions, including revitalisation of degraded areas. What is also worth to emphasize, with the LEAZ creation process, the communes attractiveness as a location for business operations is increasing. 
On the other hand, the creation of an industrial zone in rural areas is also followed by negative consequences such as spatial conflicts caused by large cubature buildings that do not fit into the rural landscape, and an increase in traffic around the zone, or environmental pollution. It should be mentioned that firms on rural areas have access to a smaller amount of high skilled workers. Differences in the density and frequency of public transport make rural jobs less accessible and force to car ownership (Hodge et al., 2002; de Hoyos, Green, 2011).

In the work, the main aim was to examine the positive effects of the functioning of local economic activity zones in rural areas. For the purposes of the work, it was assumed that socio-economic development is a process of oriented and irreversible changes in the structure of the object (commune). The change is understood as the transition from one state of the object to another, which involves a modification of its properties or features that may have both quantitative and qualitative nature. On the other hand, the structure is interpreted as all relations that occur between the components of the object and between the object and its environment (Chojnicki, 1999). The commune is treated as a local territorial social system working for its economic development and stimulating this development using local resources and defining limitations (Chojnicki, 1988).

One of the categories of socio-economic development is the multifunctionality. This concept assumes the introduction of non-agricultural functions into the rural economic space that cause the diversification of the labour market, livelihoods of the rural population (e.g. Kostrowicki, 1976; Kłodziński, 1996; Rosner, 1997). The effect is observed in the diversification of the local economy and changes in spatial development. The postulated increase in the number of business entities is to lead to an improvement in the socio-economic situation, including the quality of life of the rural areas inhabitants. As a result, the attractiveness of the countryside increases as a place to live and, consequently, the surge of people is expected (Wortman, 1990; Woods, 2005).

Therefore, creating of local economic activity zones can potentially lead to positive development effects, also in the context of multifunctionality. The final point is an entrepreneurial and active on labour market society that generate income from non-agricultural sources. The zones can support the multifunctional development on rural areas, leading to the break with the dominant agricultural-based development model. It is also possible, because in rural areas the availability and prices of real estates is usually lower than within cities. This situation may support an additional incentive for locating zones in the countryside (e.g. Miyagiwa, 1993).

\section{LOCAL ECONOMIC ACTIVITY ZONES IN WIELKOPOLSKIE VOIVODESHIP}

Local economic activity zones, which perform the conditions of theoretical model, were selected for the study. It means that they are privileged and partially formalised. In that, it was possible to determine the specific moment of their creation. Moreover, the selected LEAZs are active i.e. at least one economic entity operate within the zone.

The study involved 25 local economic activity zones located in 17 poviats of the Wielkopolskie voivodeship. The most of them belong to Poznań poviat (Figure 1). They are unevenly distributed. The vast majority of zones is located near the Poznań and Kalisz-Ostrów agglomerations and along the main national routes such as A2 motorway and the Poznań-Wrocław road (Figure 1). 
Figure 1. Spatial distribution of selected local economic activity zones

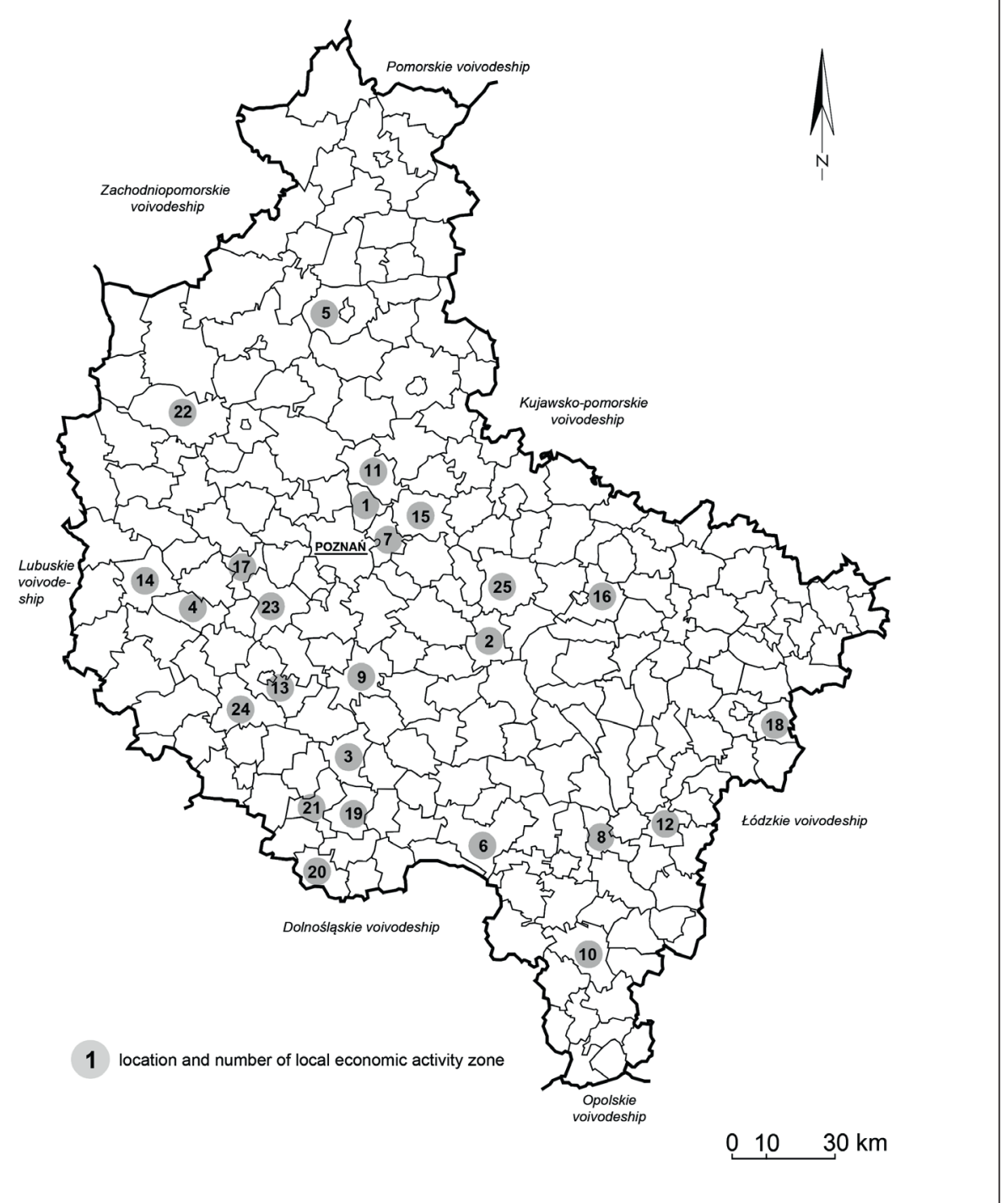

(1) Strefa Działalności Gospodarczej Czerwonak-Bolechowo, (2) Wielkopolskie Centrum Logistyczne, (3) Gostyńska Strefa Przemysłowa w Czachorowie, (4) Grodziska Strefa Przemysłowa, (5) Podstrefa Kostrzyńsko-Słubickiej SSE Chodzież w Podaninie, (6) Podstrefa Wałbrzyskiej SSE Krotoszyn, (7) Podstrefa Kostrzyńsko-Słubickiej SSE Swarzędz w Jasinie, (8) Podstrefa Łódzkiej SSE Nowe Skalmierzyce w Ociążu, (9) Śremski Park Inwestycyjny, (10) Podstrefa Łódzkiej SSE Ostrzeszów w Rojowie, (11) Goślińska Strefa Przemysłowa, (12) Podstrefa Łódzkiej SSE Opatówek, (13) Strefa Aktywizacji Gospodarczej w Widziszewie, (14) Podstrefa Kostrzyńsko-Słubickiej SSE Nowy Tomyśl, (15) Gminna Strefa Gospodarcza w Pobiedziskach, (16) Podstrefa Łódzkiej SSE Słupca w Kątach, (17) Park Przemysłowy Buk w Niepruszewie, (18) Podstrefa Łódzkiej SSE Przykona, (19) Strefa Aktywizacji Gospodarczej Pudliszki, (20) Podstrefa Wałbrzyskiej SSE Rawicz, (21) Strefa Przemysłowa w Poniecu, (22) Podstrefa Kostrzyńsko-Słubickiej SSE Wronki, (23) Podstrefa Kostrzyńsko-Słubickiej SSE Stęszew w Strykowie, (24) Podstrefa Kostrzyńsko-Słubickiej SSE Śmigiel w Przysiece, (25) Wrzesińska Strefa Aktywności Gospodarczej.

Source: author's own work 
Sixteen of the analysed zones are located in rural areas. The others are within the city in urban-rural communes. Among the zones selected for study, 18 belong to the special economic zones, especially Łódzka SEZ, Kostrzyńsko-Słubicka SEZ, and Wałbrzyska "Invest Park" SEZ. It is worth to note that the Kamiennogórska SEZ which has subzone in Kalisz also operates in the Wielkopolskie voivodeship. However, it was not taken into account, because of the study assumptions. Similarly, the LEAZ in Mieścisko under the patronage of the Słupska SEZ was out of the research.

The distribution of local economic activity zones strongly corresponds to the diversification of the level of socio-economic development of rural areas in the Wielkopolska region. Zones exist in communes classified as developing better than average. As the literature analysis shows (Rosner, 2007; Wysocki, 2010; Bartkowiak-Bakun, 2015), the most prosperous regions are the communes located in the Poznan agglomeration, along the A2 motorway, much more often in the southern part of the voivodeship (Gostyński poviat) than in the northern one where the level of remoteness is strongly visible. Rural areas with the highest rates of the socio-economic development are characterized by a high location rent, a well-developed technical infrastructure and a high local budget revenue. At the same time, these areas are indicated by researchers as the most attractive for investing and establishing a business (Godlewska-Majkowska, 2016).

It should be noted that in the results of the research on the spatial differentiation of the level of the socio-economic development of rural areas in the Wielkopolskie voivodeship conducted at the beginning of the 21st century (before most of local economic activity zones were created; e.g. Stanny, 2009), the areas of prosperity coincided with those diagnosed as the most developed a decade later. It can be observed a domination of the Poznań poviat, its neighbouring communes, and western as well as southern parts of the voivodeship. Hence, it is sometimes emphasized that the effects of the zones are related to pre-existing conditions in a given region (Goss, Phillips, 2001). It would indicate the need to include in the interpretation of the results of the occurrence of the so-called idle effect. It describes a situation when the increase in the economic activity and the generated demand for labour would occur also without emerging of LEAZ (Kryńska, 2000).

\section{METHODS}

In the conducted research process, descriptive statistics and statistical inference methods were used, including primarily the index of average annual dynamics (rate of change) in accordance with the formula:

$$
i_{\bar{G}}=\sqrt[n-1]{\frac{y_{n}}{y_{1}}-1}
$$

$\mathrm{y}_{\mathrm{n}}$ - value of variable during the considered period,

$\mathrm{y}_{1}-$ value of the variable in the basic period,

$\mathrm{n}$ - number of periods.

The index was used to assess changes in the level of the factors describing the socio-economic development of rural areas where local economic activity zones operate. The average annual dynamics of changes in six selected indicators that could describe the level of the socio-economic development (including multifunctionality) of rural 
areas was traced throughout the period of LEAZ's operation and during the first five years after and before its creation. Thus, the zones which were created in 2013 and 2014 were included in the study. The results were referred to the average value of indicators for rural areas in the Wielkopolskie voivodeship. One of the basic arrangements was the statement that the zone brings visible effects only after some time since its creation and activation. In addition, it was examined how the indicator values change for the city in urban-rural communes where the local economic activity zone is located, in relation to the neighbouring rural area.

Above-mentioned results classified in two groups (changes before and after creating a LEAZ) have been compared using the Mann-Whitney U test which is a nonparametric test allowing two groups or conditions to be compared without making the assumption that values are normally distributed. Statistics is described by equation:

$$
U=n m+\frac{n(n+1)}{2}-\sum_{x_{i}} \operatorname{Rank} x_{i}
$$

$N, m$ - sample size,

$R$ - sum of ranks.

The null hypothesis asserts that the medians of the two samples are identical.

The analysed parameters from the period 1995-2018 are:

- number of employed persons per 1,000 inhabitants,

- number of business entities per 1,000 inhabitants,

- commune revenue per capita (in PLN),

- population,

- length of the active sewage network (in km),

- dwelling stock - number of apartments.

The selected indicators result from literature studies. Similar factors were used in the reports about the effects of the special economic zones in Poland (Kryńska, 2000; Ciżkowicz et al., 2015; Trzciński et al., 2016). This selection is based also on the diagnosed potential effects of LEAZs and the data availability. New economic entities can create new jobs which could be an answer for the problem of unemployment in countryside. From the same point of view local firms can find co-operators in the local economic activity zone. Local governance in turn want to see in new enterprises an opportunity of income from taxes. On the other side, the development of LEAZs is linked with a need of technical infrastructure extension. When the LEAZ is large and generate the multiplier effects, the immigration an increasing demand in a housing construction might be observed. S. Halebsky (2009) describes big entities in small towns as the largest local employer and local taxpayer, the leading purchaser of locally produced products, and the dominant seller of consumer goods.

\section{Results}

Analysing the index of the average annual dynamics of the socio-economic factors change for communes (only in rural areas) where the local economic activity zone operates, it can be confirmed that they are higher or at least comparable with the value of the same indicators for all rural areas of the Wielkopolska region. Only in the case of the commune's revenue per capita does the reverse dependence occur. These results 
would confirm the thesis that LEAZs exist in space with a higher than average level of development. The biggest difference is visible in the case of the number of employed. In communes with LEAZ, the index was of 3.31\%, while in rural areas of voivodship - only 1.92 (Table 1).

It was observed that only in about $56 \%$ of communes with LEAZ, there was a favourable change in a given parameter within a period of five years after creation compared to the corresponding period before its creation.

The results for the indicator describing the change in the number of employed persons per 1,000 inhabitants are the most significant and positive. In approximately $2 / 3$ of the selected communes, the average annual dynamics of change was higher than average, and in 12 cases more than twice. In addition, the effect of an increase in the change in the dynamics of the employees' number was observed during the first five years of the zone's operation compared to the period of five years before its creation in $80 \%$ of cases. In the examined years, the most favourable result was recorded in the Stare Miasto commune where in 2001 in Modła Królewska (near the A2 motorway junction) the Wielkopolska Logistics Centre and other production and commercial facilities were established. During the first five years of the 21st century, there was a relevant average annual dynamics' increase in the number of employed persons per 1,000 inhabitants compared to the end of the 1990s. The change was from $-6.67 \%$ to $17.85 \%$. Really beneficial results were observed also in the communes of Grodzisk Wielkopolski, Pobiedziska, Gostyń, and Buk.

Observed clearly positive changes may be associated with the emergence of LEAZ, and more specifically with their activation and a start of large enterprises in their area (Figure 2; the point marks the moment of starting a business entity in LEAZ). Another example is Chodzież commune where in 2011 the "Europol Meble" company started within the SEZ subzone and employed approximately 1,000 people. As a result, the total number of employed persons at the end of 2012 in rural part of commune increased by over two and a half times compared to the previous year.

Similarly, in the Nowe Skalmierzyce commune, the increase in the number of employees coincided with the establishment and then extension of Correct plant in 20062008. A distinctive boost was recorded in the rural part of the Września commune in 2015-2018, i.e. after the launch of the Wrzesińska Economic Activity Zone where the Volkswagen company, one of the largest foreign investments in Poland, opened the plant. However, in most studied cases, there were no outliers or extreme changes in the indicator value, but rather they remained at a similar level.

After the creation of the zone, the population increased faster than in previous years in more than half of the analysed communes. However, in this case the interpretation should be careful due to the fact of positive location of communes with LEAZ. Probably, other factor could play more important role.

The situation is similar in the case of dwelling stock. The average annual growth of this indicator in group of communes where LEAZ functioning was higher than the average in the rural areas of Wielkopolskie voivodeship in 13 of 25 cases. However, in the analysis of the period of five years after the creation of the zone compared to previous years, a significant increase in this indicator is measurable. Exactly 21 out of 25 communes recorded an increase. On the one hand, for the vast majority of the communes in the analysed voivodeship this value increased; hence, it is difficult to clearly indicate a significant relationship between the newly built flats and the appearance of 


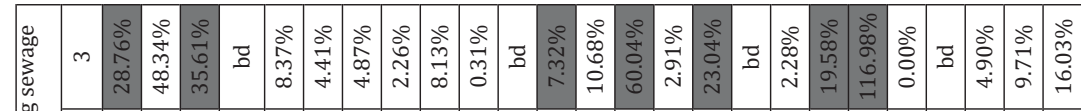

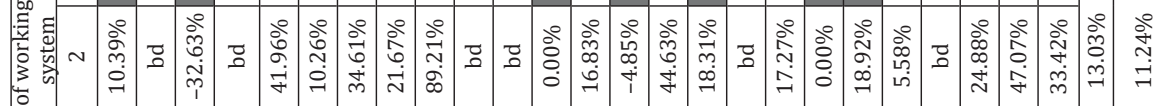

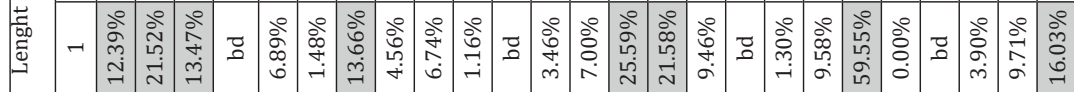

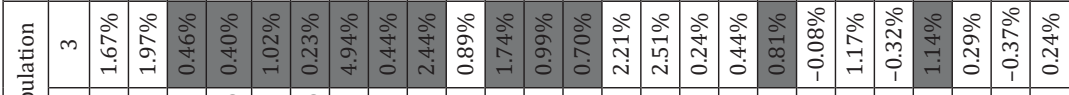

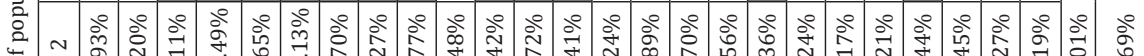

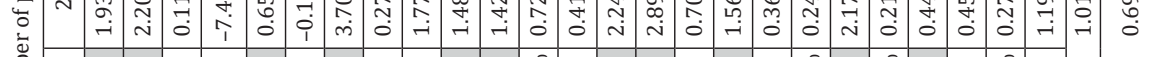

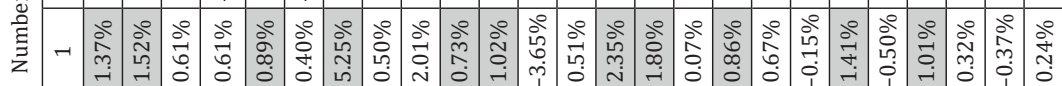

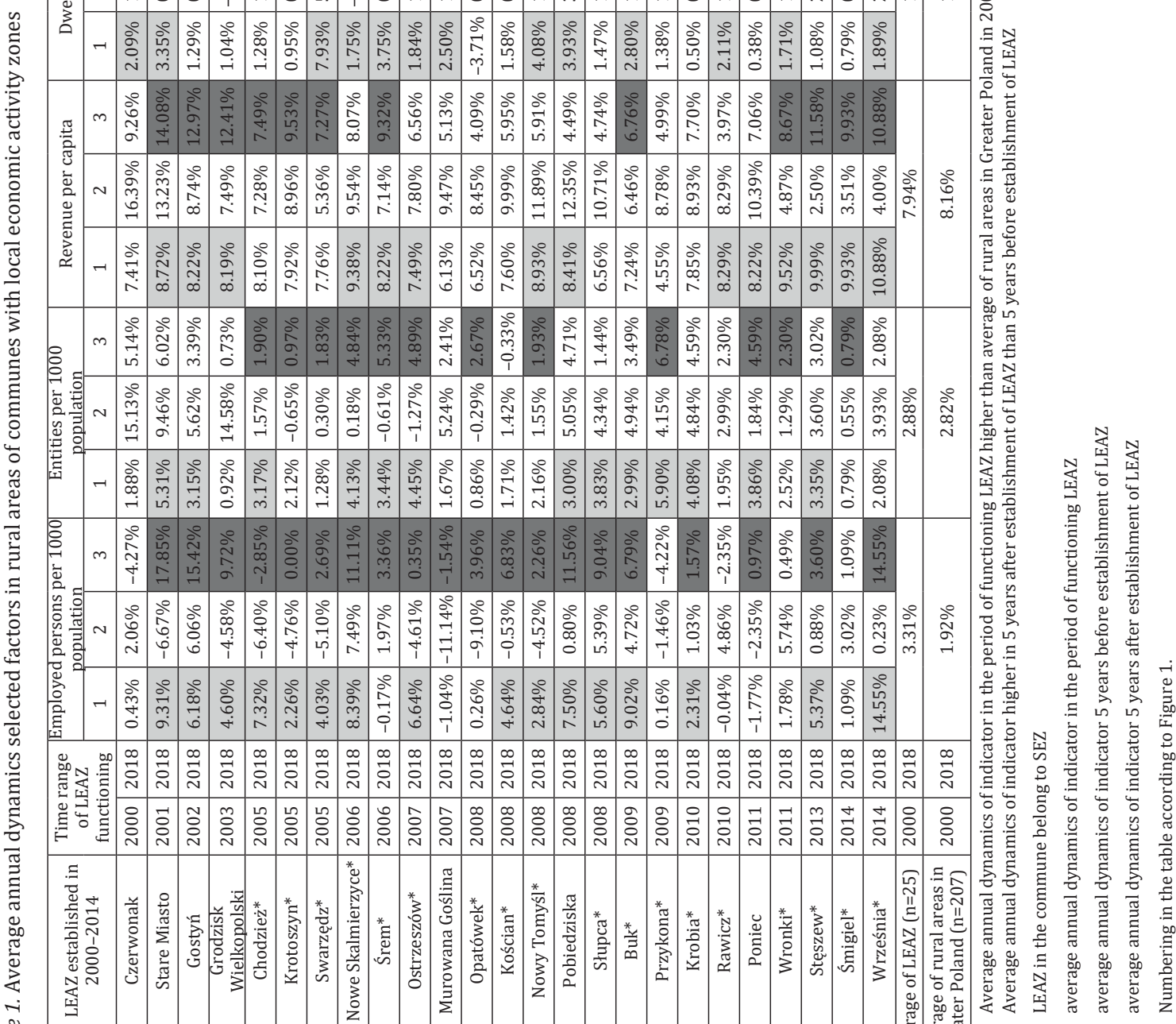

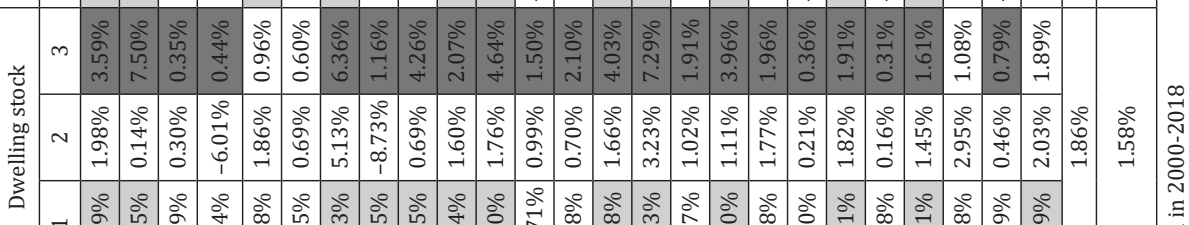

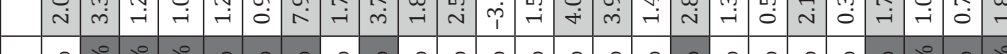
言

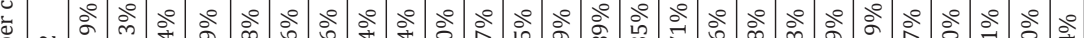
每

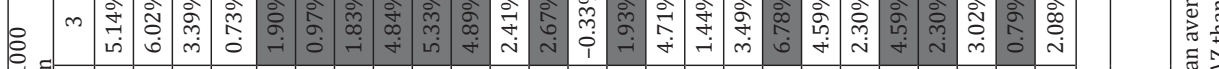

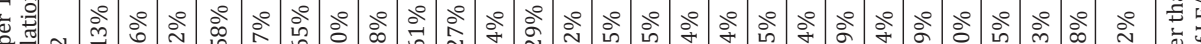

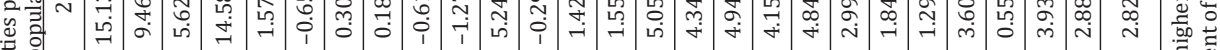

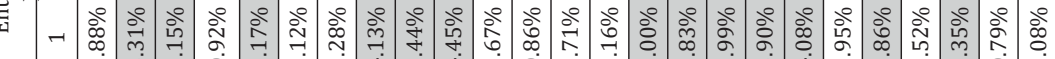

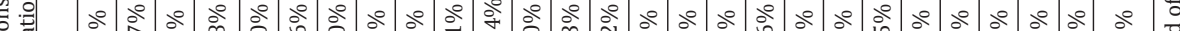

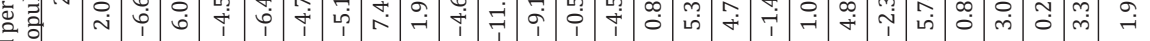

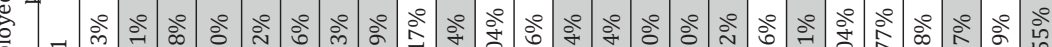


Figure 2. Change of employees number in selected communes in 2006-2018

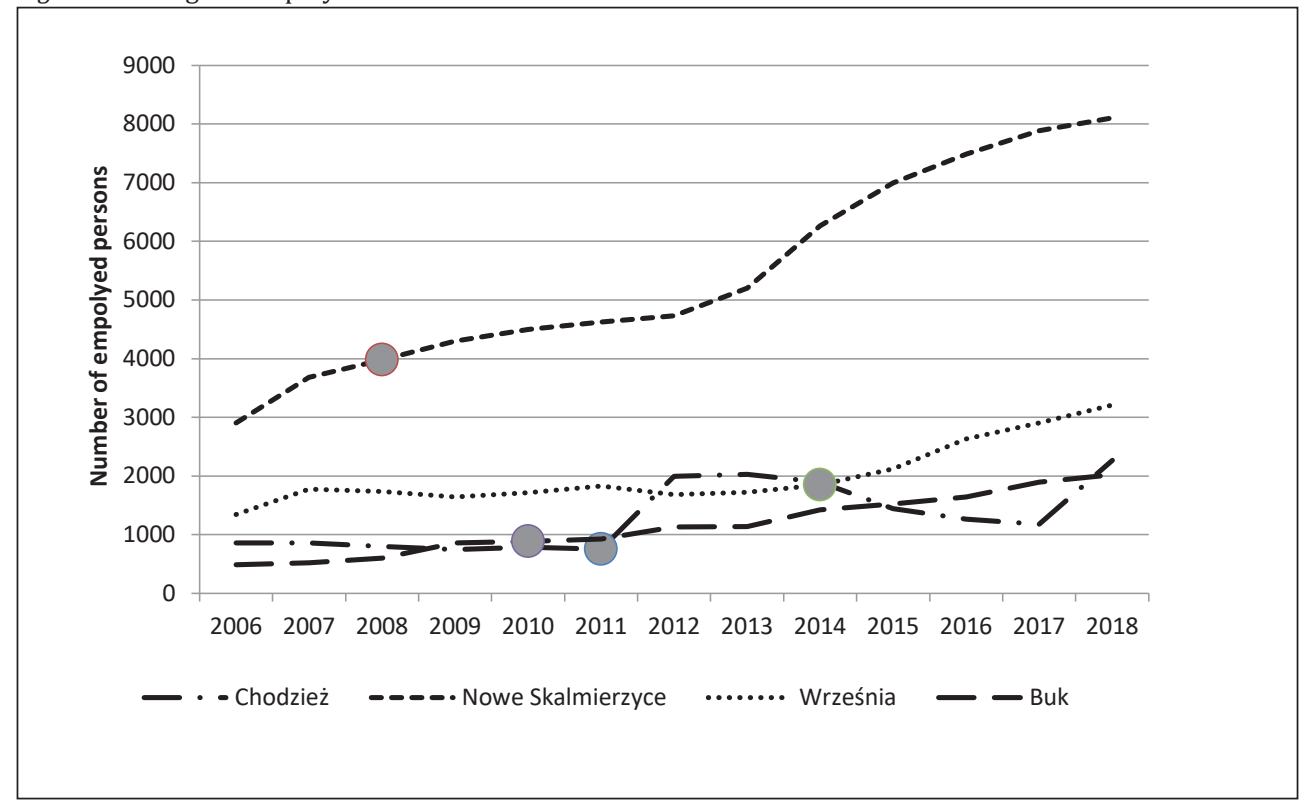

* starting of large business entity marked as a point

Source: author's own work based on Central Statistical Office data

the zone. On the other hand, the increase in the number of employed and the increase in the population may be the result of new jobs that has been created in the zone plants.

In more than half of the cases during the LEAZ's operation, there was an increase in the number of enterprises in the voivodeship higher than average. In almost $50 \%$ of communes, this factor had higher value in the first 5 years of operation of organised zones than before their creation. However, in fact the observed phenomenon would occur anyway (idle effect). The zone rather contributed to strengthening these positive results. In communes with a less favourable geographical location, the average annual rate of the change in the analyzed indicator decreased (Grodzisk Wielkopolski). The gradual spatial expansion of the zone and from time to time newly-opened medium-sized enterprises could have had an impact on an increase in the number of employees.

The influence of the zone on the budget revenue of the commune is not explicitly confirmed. Although, communes recorded a higher than average annual dynamics of this parameter, less than half of them recorded better results five years after the creation of LEAZ than five years before. It is probably an effect of both the insufficient scale of budget revenues generated by entities operating in the zone and delaying this effect in time, due to the existing tax breaks. It should be noted that the change in the value of money has not been taken into account.

No relationship was observed between the development of the sewage system length and the creation of a local economic activity zone, largely due to incomplete data.

The result of the above analysis has been summarised in the Mann-Whitney U test and are presented in Table 2. This test indicates that there are significant differences at the $5 \%$ significance level between the change of value of three parameters before and 
after creating a zone. The number of the employed persons per 1,000 inhabitants, the commune revenue per capita, and the number of the apartments are in this group.

Table 2. Results of the Mann-Whitney U test - change of factors five years before and five years after creating the LEAZ

\begin{tabular}{|l|c|c|c|}
\hline \multicolumn{1}{|c|}{ Parameter } & $U$-value & $Z$-score & $p$-value \\
\hline number of employed persons per 1,000 inhabitants & 208.5 & 2.008 & $0.044^{*}$ \\
\hline number of business entities per 1,000 inhabitants & 259.5 & 1.019 & 0.308 \\
\hline commune revenue per capita & 165.0 & 2.852 & $0.004^{*}$ \\
\hline population & 290.0 & 0.427 & 0.667 \\
\hline length of the active sewage network & 256.0 & 1.087 & 0.276 \\
\hline number of apartments & 186.5 & 2.435 & $0.015^{*}$ \\
\hline
\end{tabular}

*significant at $\mathrm{p}<0.05 ; \mathrm{n}=25$

Source: author's own work

What is worth to note, there are no significant differences between the effects of the operation of zones belonging to special economic zones and the others. However, they were not evenly represented. Only in the case of a change in the number of economic entities after the creation of the zone, communes not belonging to the SEZ recorded an unsatisfactory balance. In one case of seven an increase was recorded, while in communes belonging to SEZs, this increase was noticeable in 10 communes.

Moreover, the cases of urban-rural communes revealed in the analysis, in which the zone was organised in the city, are especially noteworthy. It turns out that in the case of the indicator regarding the number of business entities per 1,000 people, none of such cities recorded a higher dynamics than in the rural area of a given commune. In all cases, entrepreneurship grew at a faster rate in the countryside than in the city. On the one hand, it is impossible to state unequivocally whether other factors had a decisive influence here. On the other hand, it is difficult to say that the effect of the creation of the zone occurred only in the city. Similar observations were made for the indicator of the number of flats, population, or the length of the sewage system. The marginal case is the Poniec commune where the situation was opposite: the indicators in the city grew faster than in the countryside.

Once again, the exception is the average annual dynamics of change in the number of employed persons per 1,000 inhabitants. In four cities the indicator was positive and higher in the city than in the rural part of commune. A particularly noticeable difference was recorded in Wronki where this effect can be associated with the opening of the Samsung factory in 2010 .

\section{DISCUSSION AND LIMITATIONS}

The presented results of the research conducted in the Wielkopolskie voivodeship on local economic activity zones reflect and confirm to some extent other studies about the effects of organized and privileged investment areas both in Poland and in the world. The subject of the impact of special economic zones and investors on the local socio-economic development has been popular for many years, intensified in Poland since the 1990s, after political and economic transformation. However, the results published so far, apply only to special economic zones, ignoring the other zones. What 
is more, past observations do not include evaluation of the effect on rural areas. The presented work is an extension and comparison of the research conducted on another sample and in another period, published by B. Wojtyra (2019). In this cited work, economic activity zones not belonging to special economic zones were examined in detail for the first time in Poland.

The effects of SEZ operation are vague, thus difficult to assess. Although positive voices prevail, mainly due to the improvement of the situation on local labour markets (an increase in the number of employees also observed in the presented analysis), criticism is also often present. In international literature, the diagnosed effects of privileges for business entities were described as positive (Aggarwal, 2007; Givord et al. 2011; Mayer et al., 2013; Wang, 2013; Woźniak, 2015), neutral (Neumark, Kolko, 2008; Gobillion et al. ., 2012) or negative (Billings, 2009). D. Bondonio and J. Engberg (2000) emphasized even the lack of very significant impact of the zones on the local labour markets. Many publications have confirmed the positive effects of the first period of the SEZ (or tax incentives in general) on employment and investment (e.g. House, Shapiro, 2006). What is very often indicated, the effects strength and importance of economic activity zones depends on various, local conditions and resources (Bondonio, 2003).

In the Polish research field, the most important work in this area was published by E. Kryńska (2000), where we can found the observations after the first years of SEZ operation in Poland. Their positive impact on improving the situation on the labour markets, although noticeable, was defined as limited and not fulfilling the hopes repose in them. Kryńska's team diagnosed the occurrence of the mentioned idle effect and substitution effect (crowding out of pre-existing economic activity). B. Domański and K. Gwosdz (2005) are positive about the results of establishing the Euro-Park Mielec SEZ. Generally, the significant impact of SEZ on the local development is presented in works constituting the characteristics of individual case studies and newer works (Rydz, 2004; Fiedor, 2007; Woźniak, 2014; Ciżkowicz et al., 2015). In contrast, in comprehensive research appear more critical views.

One of the latest reports about the impact of special economic zones on employment indicates only a partial success of the SEZ in Poland (Trzciński et al., 2016). According to the authors, they do not affect the reduction of unemployment at the local level, but are significantly correlated with the increase in the number of working people. The report found a positive influence on the number of small enterprises as well as.

In Polish literature can be found works about the general meaning of large enterprises in rural economic space. For example, M. Dej (2009) concludes that communes where large entities (more than 200 employees) are located differ in a significant way from other communes. Differences were observed in the tendency of migration, level of enterprise or even investments into technical infrastructure. The author emphasized that more advantageous situation was noticed in communes where large investments had taken place.

A few works would directly speak about the effects of economic activity zones on rural areas. As noted by S. Frick and A. Rodriguez-Pose (2019: 88), SEZs "contribute to the growth of surrounding areas, but this effect suffers from strong distance decay. The immediate vicinity benefits and the influence of zones is still felt within a 50-km radius, but the effect at the latter distance is much weaker, when not outright insignificant". The authors pointed to the special importance of cities in the development of the zones. The negative effects of creating zones for rural areas can be found in India which is, 
however, primarily associated with the allocation of land for these investments (e.g. Parwez, Sen, 2016).

The results presented in the paper are certainly not without limitations, thus the conclusions should be formulated carefully. Firstly, the study was conducted on a small sample of 25 economic activity zones limited only to the Wielkopolskie voivodeship. However, this selection allowed for a deeper understanding of local conditions and led to conduct qualitative assessment of the effects. Besides, this procedure gave an opportunity to better formulation of the causes in the observed phenomenon. Basically, selected 25 communes in this work have been treated as case studies. Extracting them according to the definition, required numerous studies on content analysis. Nevertheless, in the future it is planned to extend the study to a larger territorial scope. Secondly, the study used a short time range depending on periods of LEAZs existing. Thirdly, restrictions were diagnosed for some data resources. Thus, the assessment of the relationship between the existence of the zone and the development of the sewage system length gave an incomplete picture. In the case of gaps in the database for individual years, the data coming from the following year in time series was used. Finally, it should be said that the number of the employed persons in given commune does not equal existing workplaces, because people can work in other commune and they are demonstrated in this stats. Data about workplaces in this level is not available in Poland.

\section{CONCLUSIONS}

The main purpose of the work was to determine the impact of selected 25 local economic activity zones operating in the Wielkopolskie voivodeship on the development of rural areas of the communes in which they are located. The analysis shows that the average annual dynamics of the change indicators in communes where the local economic activity zone operate are higher or at least comparable with the average of the same parameters for all rural areas in the Wielkopolskie voivodeship. Anyway, it is difficult to state unequivocally whether the observed effect is the result of only the activities of business entities in the zone since privileged investment areas overlap with areas that developed better than on average before the LEAZs were established. Therefore, it can be presumed that LEAZs are a strategy for increasing the competitiveness of communes with a higher level of development, not a panacea for the problems of communes affected by remoteness. Hence, establishing a local economic activity zone is not a universal solution that will be working in all conditions.

Positive effects observed in the values of the socio-economic indicators may be related to the functioning of the local economic activity zones, especially in the employed persons; number. In this study, it has mainly been diagnosed the beneficial effect of the large economic entities presence operating in the zone on employment growth in the countryside.

However, even above-average measureable changes in parameter values may not always be justified by the presence of LEAZ. This situation occurs in the case of a growing number of flats which, as it turns out, is a common phenomenon in rural areas of the Wielkopolskie voivodeship. It is worth to mention that in the vast majority of the cases the change in the value of indicators were development-oriented, even if the differences between the communes with LEAZ and rest of the voivodeship were not considerable. Interestingly, the effect of the zone's operation was more clearly noticeable in the 
rural area than in the city, in the case of zones located in the city area in urban-rural communes.

Based on the results of the study, it can be concluded that only in the case of local economic activity zones that have achieved significant success thanks to investment of large concerns (e.g. Wrzesińska SAG, Gostyńska Industrial Zone, Industrial Park Buk) the measurable and beneficial impact on the socio-economic development has been diagnosed.

\section{References}

Allen, A., Tynel, P. (2011). Specjalne strefy ekonomiczne po 2020 roku. Analiza dotychczasowej działalności oraz perspektywy funkcjonowania. Ernst\&Young.

Aggarwal, A. (2007). Impact of Special Economic Zones on Employment, Poverty and Human Development. New Delhi: Indian Council for Research on International Economic Relations, Working Paper, 194.

Bański, J. (2008). Wiejskie obszary sukcesu gospodarczego. Przegląd Geograficzny, 80(2), 199222.

Bartkowiak-Bakun, N. (2015). Zróżnicowanie poziomu rozwoju społeczno-gospodarczego obszarów wiejskich województwa wielkopolskiego. Roczniki Naukowe Ekonomii Rolnictwa i Rozwoju Obszarów Wiejskich, 102(2), 7-13.

Billings, S. (2009). Do Enterprise Zones Work? An Analysis at the Borders. Public Finance Review, $37,68-93$.

Blakely, E.J., Bradshaw, T.K. (2002). Planning local economic development. Theory and practice. Third edition. New Delhi, London: Thousand Oaks Sage Publications.

Bondonio, D., Engberg, J. (2000). Enterprise zones and local employment: Evidence from the States' Programs. Regional Science and Urban Economics, 30, 519-549.

Bondonio, D. (2003). Do Local Tax Incentives Affect Economic Growth? What Mean Impacts Miss in the Analysis of Enterprise Zone Policies, Working Papers No. 03-17, Center for Economic Studies, U.S. Census Bureau.

Ciżkowicz, P., Ciżkowicz-Pękała, M., Pękała, P., Rzońca, A. (2015). The effects of special economic zones on employment and investment: spatial panel modelling perspective. Warszawa: Economic Institute, NPB Working Paper, 208.

Chojnicki, Z. (1988). Koncepcja terytorialnego systemu społecznego. Przegląd Geograficzny, LX(4), 491-510.

Chojnicki, Z. (1999). Podstawy metodologiczne i teoretyczne geografii. Poznań: Bogucki Wydawnictwo Naukowe.

Dej, M. (2009). Large enterprises as a factor triggering social and economical changes in the polish countryside outside the metropolitan areas. Revija za geografijo. Journal for Geography, $4(2), 87-102$.

Domański, B. (2001). Kapitał zagraniczny w przemyśle Polski. Prawidłowości rozmieszczenia, uwarunkowania i skutki. Kraków: Instytut Geografii i Gospodarki Przestrzennej UJ.

Domański, B., Gwosdz, K. (eds.). (2005). Dziesięć lat doświadczeń pierwszej polskiej specjalnej strefy ekonomicznej, Kraków-Mielec: Instytut Geografii i Gospodarki Przestrzennej UJ, Agencja Rozwoju Przemysłu S.A., Oddział w Mielcu, Urząd Miejski, Mielec.

Domański, B., Gwosdz, K. (2010). Multiplier effects in local and regional development. Quaestiones Geographicae, 29(2), 27-37.

Fiedor, B. (2007). Wałbrzyska Specjalna Strefa Ekonomiczna Invest-Park. Bilans pierwszej dekady, wpływ na region i perspektywy rozwoju. Wrocław: Wydawnictwo Akademii Ekonomicznej im. Oskara Langego.

Frick, S., Rodríguez-Pose, A. (2019). Are special economic zones in emerging countries a catalyst for the growth of surrounding areas? Transnational Corporations, 26(2), 75-94.

Givord, P., Quantin, S., Trevien, C. (2012). A Long-term Evaluation of the First Generation of French Urban Enterprise Zones. Institut National de la Statistique et des Études Économiques, France. 
Godlewska-Majkowska, H. (eds.) (2016). Atrakcyjność inwestycyjna regionów 2016. Województwo wielkopolskie. Warszawa: Polska Agencja Informacji i Inwestycji Zagranicznych S.A. w Instytucie Przedsiębiorstwa Szkoły Głównej Handlowej w Warszawie.

Goss, E., Phillips, J. (2001). The Impact of Tax Incentives: Do Initial Economic Conditions Matter? Growth and Change, 32, 236-50

Gobillion, L., Magnac, T., Laurent, H. (2012). Do Unemployed Workers Benefit From Enterprise Zones? The French experience. Journal of Public Economics, 96, 881-892.

Halebsky, S. (2009). Small towns and big business: challenging Wal-Mart superstores. Lanham, MD: Lexington Books.

Heffner, K. (2002). Rola małych miasteczek w rozwoju terenów wiejskich. In: M. Kłodziński, B. Fedyszak-Radziejowska (eds.). Przedsiębiorczość wiejska w Polsce i krajach Unii Europejskiej. Warszawa: PAN, 74-100.

Heffner, K. (2003). Małe miasta a rozwój obszarów wiejskich. In: A. Stasiak (ed.). Problemy zagospodarowania terenów wiejskich w Polsce, Biuletyn KPZK PAN, 207, 227-246.

Heffner, K. (2005). Czynniki rozwoju obszarów wiejskich - rola małych miast. In: A. Rosner (ed.). Uwarunkowania i kierunki przemian społeczno-gospodarczych na obszarach wiejskich. Warszawa: IRWiR PAN, 299-330.

Heffner, K., Marszał, T. (eds.). (2005). Problemy rozwoju małych miast w wymiarze lokalnym i regionalnym. Biuletyn KPZK PAN, 220.

Hodge, J., Dunn, S., Monk, M. (2002). Fitzgerald Barriers to participation in residual rural labour markets. Work, Employment and Society, 16, 457-476.

House, C.L., Shapiro, M.D. (2006). Phased-In Tax Cuts and Economic Activity. American Economic Review, 96(5), 1835-1849.

Hoyos, de, M., Green, A. (2011). Recruitment and retention issues in rural labour markets. Journal of Rural Studies, 27, 171-180.

Informacja o realizacji ustawy o specjalnych strefach ekonomicznych. Stan na 31 grudnia 2016 r. (2017).

Jarczewski, W. (2007). Pozyskiwanie inwestorów do gmin. Warszawa: Wydawnictwo Wolters Kluwer.

Kłodziński, M. (1997). Istota wielofunkcyjnego rozwoju terenów wiejskich. In: M. Kłodziński, A. Rosner (eds.). Ekonomiczne i społeczne uwarunkowania i możliwości wielofunkcyjnego rozwoju wsi w Polsce. Warszawa: Wydawnictwo SGGW, 41-67.

Knickel, K., Renting, H. (2000). Methodological and conceptual issues in the study of multifunctionality and rural development. Sociologia Ruralis, 40(4), 512-528.

Kostrowicki, J. (1976) Obszary wiejskie jako przestrzeń wielofunkcyjna. Zagadnienia badawcze i planistyczne. Przegląd Geograficzny, 48(4), 601-611.

Kryńska, E. (ed.). (2000). Polskie specjalne strefy ekonomiczne - zamierzenia i efekty, Warszawa: Wydawnictwo Scholar.

Matykowski, R., Siwek, M. (2008). Proces „pączkowania” podstref w ramach specjalnych stref ekonomicznych. In: D. Świątek, M. Bednarek, P. Siłka (eds.). Współczesne problemy badawcze geografii polskiej - geografia człowieka. Dokumentacja Geograficzna, 36, 213-217.

Mayer, T., Mayneris, F., Py, L. (2013). The Impact of Urban Enterprise Zones on Establishments' Location Decisions: Evidence From French ZFUs'. Banque de France Working Paper, 458.

Miyagiwa, K. (1993). The locational choice for free-trade zones. Rural versus urban options. Journal of Development Economics, 40, 187-203.

Neumark, D., Kolko, J. (2008). Do Enterprise Zones Create Jobs? Evidence From California's Enterprise Zone Program. NBER Working Papers No. 14530, National Bureau of Economic Research.

OECD (2006). The New Rural Paradigm: Policies and Governance. OECD Rural Policy Reviews.

Parwez S., Sen V. (2016). Special Economic Zone, Land Acquisition, and Impact on Rural India. Emerging Economy Studies, 2(2), 223-239.

Ploeg, van der, J.D., Roep, D. (2003). Multifunctionality and Rural Development: The Actual Situation in Europe. [In:] G. van Huylenbroeck, G. Durand (eds.), Multifunctional Agriculture: A New Paradigm for European Agriculture and Rural Development. Burlington Ashgate, Aldershot, 37-54. 
Rachwał, T., Wiedermann, K. (2008). Multiplier effects in regional development: The case of the motor vehicle industry in Silesian voivodeship (Poland). Quaestiones Geographicae, 27B, 67-80.

Rosner, A. (1997). Demograficzne uwarunkowania wielofunkcyjnego rozwoju na obszarach wiejskich. In: M. Kłodziński, A. Rosner (eds.). Ekonomiczne i społeczne uwarunkowania i możliwości wielofunkcyjnego rozwoju wsi w Polsce. Warszawa: SGGW, 137-158.

Rosner, A. (ed.) (2007). Zróżnicowanie poziomu rozwoju społeczno-gospodarczego obszarów wiejskich a zróżnicowanie dynamiki przemian, Warszawa: IRWiR PAN.

Rydz, E. (2004). Proces kształtowania się Słupskiej Specjalnej Strefy Ekonomicznej. Prace Komisji Geografii Przemysłu Polskiego Towarzystwa Geograficznego, 7, 9-23.

Stanienda, J. (2011). Determinanty rozwoju stref aktywności gospodarczej. Zeszyty Naukowe MWSE w Tarnowie, 1(17), 255-265.

Stanny, M. (2009). Zróżnicowanie poziomu rozwoju obszarów wiejskich w Polsce a problem realizacji polityki spójności. Zeszyty Naukowe SGGW w Warszawie, Polityki Europejskie, Finanse i Marketing, 1(50), 47-56.

Stanny, M. (2011). Typologia wiejskich obszarów peryferyjnych pod względem anatomii struktury społeczno-gospodarczej. Wieś i Rolnictwo, 2(151), 59-75.

Stryjakiewicz, T. (1999). Adaptacja przestrzenna przemysłu w Polsce w warunkach transformacji. Poznań: Wydawnictwo Naukowe UAM.

Tobolska, A. (2010). Miejsce inwestora zagranicznego w przestrzeni lokalnej i regionalnej na przykładzie Swedwood w Chlastawie. Poznań: Bogucki Wydawnictwo Naukowe, Seria „Studia i Prace z Geografii i Geologii", 5.

Trzciński, R., Stasiowski, J., Konieczna-Sałamatin, J., Skórska, P., Bienias, S., Weremiuk, A. (2016). Wpływ specjalnych stref ekonomicznych na zatrudnienie. Ocena skutków regulacji ex post ustawy o specjalnych strefach ekonomicznych z dnia 20 października 1994 roku (Dz.U. 1994 Nr 123 poz. 600 z późn. zm.). Raport Ocena skutków regulacji oparta na dowodach. Model wykorzystania istniejących dowodów analityczno-ewaluacyjnych w procesie oceny społeczno-ekonomicznych efektów planowanych regulacji. Warszawa.

Ustawa z dnia 20 października 1994 r. o specjalnych strefach ekonomicznych (tekst jednolity: Dz. U. z 2019 r. poz. 482).

Van Huylenbroeck, G., Durand, G. (2003). Multifunctionality and rural development: a general framework. Multifunctional Agriculture: a new paradigm for European agriculture and rural development. Ashgate Publishing, 1-16.

Wang, J. (2013). The Economic Impact of Special Economic Zones: Evidence from Chinese Municipalities. Journal of Development Economics, 10, 133-147.

Wojtyra, B. (2014). Strefy aktywności gospodarczej w teoriach rozwoju lokalnego. Biuletyn Rozwój Regionalny i Polityka Regionalna, 28, 25-35.

Wojtyra, B. (2016). Funkcjonowanie lokalnych stref aktywności gospodarczej na obszarach wiejskich województwa wielkopolskiego. Prace Komisji Geografii Przemysłu Polskiego Towarzystwa Geograficznego, 30(2), 95-107.

Wojtyra, B. (2019). Lokalne strefy aktywności gospodarczej w procesie rozwoju obszarów wiejskich województwa wielkopolskiego. Poznań: Bogucki Wydawnictwo Naukowe.

Woods, M. (2005). Rural Geography: processes, responses and experiences in rural restructuring. Sage, London.

Wortman, M.S. Jr. (1990) Rural entrepreneurship research: an integration into the entrepreneurship field. Agribusiness, 6(4), 329-344.

Woźniak, E. (2014). Wałbrzyska Specjalna Strefa Ekonomiczna na tle pozostałych stref w Polsce - analiza efektów funkcjonowania w latach 2000-2013. [In:] J. Knopek, M. Sikora-Gaca, R. Gabryszak (eds.), Polska w Europie 1989-2014. 25 lat po przemianach. Przykładowe obszary przekształceń gospodarczych. Koszalin: Wydawnictwo Politechniki Koszalińskiej, 127-151.

Woźniak, E. (2015) Funkcjonowanie specjalnych stref ekonomicznych w Federacji Rosyjskiej. Prace Komisji Geografii Przemysłu Polskiego Towarzystwa Geograficznego, 29(2), 66-78.

Wysocki, F. (2010). Metody taksonomiczne w rozpoznawaniu typów ekonomicznych rolnictwa i obszarów wiejskich, Poznań: Wydawnictwo Uniwersytetu Przyrodniczego w Poznaniu. 
Bartosz Wojtyra, BEng, PhD, Adam Mickiewicz University, Faculty of Human Geography and Planning, Department of Agriculture and Rural Geography. He earned his PhD in Geography (Earth Sciences) from Adam Mickiewicz University in Poznań, the Faculty of Geographical and Geological Sciences (2018), worked in the Faculty of Geographical and Geological Sciences of Adam Mickiewicz University, currently Faculty of Human Geography and Planning. Author of papers about economic activity zones, local spatial policy, and beer market in Poland.

ORCID: 0000-0003-3970-6046

\section{Address:}

Faculty of Human Geography and Planning Department of Agriculture and Rural Geography Krygowskiego St. 10, 61-680 Poznań, Poland

e-mail: bwojtyra@amu.edu.pl 